\title{
AGRICULTURA FAMILIAR, FEIRAS LIVRES E FEIRANTES DO ALTO JEQUITINHONHA ${ }^{1}$
}

\section{FAIR OF FAMILY FARMS AT ALTO JEQUITINHONHA}

\author{
Maria Sirlene da Cruz \\ Universidade Federal de Minas Gerais, Instituto de Ciências Agrárias, Montes Claros, MG, Brasil \\ sirlenecruz.mg@gmail.com \\ Eduardo Magalhães Ribeiro \\ Universidade Federal de Minas Gerais, Instituto de Ciências Agrárias, Montes Claros, MG, Brasil \\ eduardoribeiromacuni@gmail.com \\ Miguel Ângelo Perondi \\ Universidade Tecnológica Federal do Paraná, Pato Branco, PR, Brasil \\ miguelangeloperondi@gmail.com \\ Daniel Coelho de Oliveira \\ Universidade Estadual de Montes Claros, Departamento de Ciências Sociais, Montes Claros, MG, Brasil \\ daniel.coelhoo@yahoo.com.br \\ Heloísa de Moura Costa \\ Universidade Federal de Minas Gerais, Instituto de Geociências, Belo Horizonte, MG, Brasil \\ heloisasmcosta@gmail.com
}

\section{Resumo}

Este artigo tem por objetivo analisar a comercialização da produção da agricultura familiar nas feiras livres de cinco municípios do Alto Jequitinhonha, Minas Gerais. O estudo se baseou em consulta à literatura e bancos de dados, e em pesquisa de campo com feirantes. Os resultados indicam que feiras livres geram parte importante das rendas desses municípios e dos agricultores, e que a diversidade de produtos ofertados nas feiras contribui para manter hábitos alimentares territorializados, reunindo segurança e soberania alimentar. No entanto, existem desafios constantes: prédios dos mercados municipais, transporte, rodovias e abastecimento de água, carecem de ações e cuidados públicos. Assim, investimentos pontuais e regulares poderiam contribuir para estimular esses circuitos de negócios que valorizam os atributos produtivos do território.

Palavras chaves: Feiras livres. Agricultura familiar. Comercialização agrícola. Vale do Jequitinhonha.

\begin{abstract}
This article aims to analyze the commercialization of family farms production in fairs of five municipalities of Alto Jequitinhonha Valley, at Minas Gerais State, Brazil. This study was based on literature and database consultation, and field research with marketers. The results indicate that fairs generate an important part of the income of these municipalities and farmers, and that the diversity of products offered at the fairs contributes to
\end{abstract}

\footnotetext{
${ }^{1}$ A pesquisa que originou este artigo foi apoiada pelo CNPq.
} 
maintaining territorialized eating habits, bringing food security and sovereignty. However, there are constant challenges: municipal market buildings, transportation, highways, and water supplies lack public action and care. Thus, some investments could help to stimulate these business circuits that value the productive attributes of the territory.

Keywords: Fair. Family farm. Agricultural marketing. Jequitinhonha Valley.

\section{Introdução}

Agricultores do Alto Jequitinhonha dizem que produzir é fácil: as técnicas foram ensinadas pelos pais; "aprenderam fazendo" e se aperfeiçoaram no correr de anos de ofício. Têm dificuldades quando o "tempo das águas" demora a chegar, quando uma seca liquida semente ou muda de qualidade que compõe o patrimônio genético zelado por cada família, ou quando um filho se casa ou migra e desarranja o cálculo da força de trabalho disponível para trabalhar no "terreno". Mas essas são daquelas dificuldades que sabem enfrentar, resolver e superar. Vender é, sempre, mais difícil para o agricultor: nas vendas enfrentam mercados anônimos e competitivos, que costumam preferir bens produzidos em larga escala, homogêneos, de preços baixos. A agricultura familiar do vale do Jequitinhonha, definitivamente, não se adequa a esses mercados.

A produção familiar é característica da agricultura do Alto Jequitinhonha. Com pouca ou nenhuma mecanização da produção - quase nada de química agrícola e um estoque de saberes, plantas e técnicas que, afirma dona Odília dos Santos, de Turmalina, "vem lá dos antigos" - usam de sistemas produtivos diferentes daqueles empregados pela agricultura da revolução verde, baseada no tripé trator/veneno/adubo. Essa agricultura familiar tem vínculos fortes com a terra herdada nas partilhas sucessivas de glebas já muito pequenas, com a produção autônoma de alimentos, trabalho familiar e ajuda comunitária. Estas características da produção são valores que fundamentam a agricultura familiar do território. Sem condições de vender nos grandes mercados, sem produção homogênea e economias de escala, essa agricultura familiar se abriga em nichos de mercados locais, desaguadouros da maior parte da produção vendável, principalmente para as feiras livres das pequenas cidades-sedes dos municípios.

Certo que o modo de vida nessas cidades é muito semelhante àquele do campo, pelo menos no trato social, nos hábitos alimentares e na sociabilidade, que valoriza 
grandemente o parentesco e o pertencimento ao lugar. São municípios que não ultrapassam 50 mil habitantes, que mantêm uma convergência de hábitos alimentares e culturais que animam as vendas da produção de alimentos essenciais na vida cotidiana produtos da agricultura, da horta, do extrativismo e das indústrias domésticas rurais.

A base dessa relação de negócios contínuos é a confiança, que envolve quem produz e quem consome, ligando o comprador com o local de origem e a técnica de produção dos alimentos. Os agricultores feirantes se esforçam para manter esse negócio que operam há décadas, e têm na feira livre seu principal canal de comercialização. Conhecer a dinâmica e as demandas das feiras é ponto de partida para ações de apoio a esse mercado próximo, culturalizado e complexo. E é isso que se busca neste artigo: analisar cinco das feiras livres do Alto Jequitinhonha para compreender estratégias de produção e venda dos feirantes, entender os sistemas de produção, a organização das vendas nas feiras e os problemas desses mercados.

\section{Metodologia da pesquisa}

Conhecer as diversas tramas desses mercados, investigar o perfil dos feirantes e a diversidade de produtos, como foi o escopo deste artigo, exigiu empregar técnicas variadas para chegar aos resultados apresentados. Foi usada aqui a combinação de técnicas qualitativas e quantitativas de pesquisa. O uso de técnicas complementares foi necessário para atingir o escopo da investigação e captar aspectos diversos dessa mesma realidade (GIL, 2002; LAVILLE \& DIONNE, 1999).

Os municípios pesquisados foram definidos em conjunto e por indicação do Centro de Agricultura Alternativa Vicente Nica, CAV, ong do Alto Jequitinhonha que atua na área do desenvolvimento e extensão rural, que sugeriu orientar o estudo para municípios em que havia organização sólida de feirantes e, portanto, condições de aproveitar a pesquisa para fortalecer ações pré-existentes. Uma vez definidos os municípios, o primeiro passo foi consultar estudos sobre feiras para conhecer métodos já utilizados, que podiam orientar escolhas, além de estabelecer linhas de base para comparações e inclusive, roteiros de entrevistas para feiras. Pesquisas anteriores ofereceram referências sólidas para adequar o roteiro semiestruturado para entrevistas com feirantes e para comparar resultados. 
Em seguida foram cumpridas etapas sucessivas de (1) coleta de dados, (2) organização e sistematização de dados, e (3) análise dos resultados.

A coleta de dados começou com o mapeamento do espaço e organização de informações por meio de visita às feiras livres em maio e junho de 2018. Foi usada planilha para (i) mapear no espaço da feira os pontos de vendas por segmentos préclassificados, (ii) contar o número de pontos de vendas e (iii) classificar os tipos de produtos existentes nas feiras. O levantamento permitiu elaborar um croqui de cada feira, discriminando a distribuição espacial dos produtos, conforme estudos de Garcia (1983) e Palmeira (2014).

Pontos de vendas foram contados por meio de planilha que segmentava produtos por categorias: frutas, legumes e verduras (FLV); indústria doméstica rural (doces, queijos, mel, rapadura, farinhas); bancas diversificadas (que vendem produtos de elaboração e produção diferentes); bancas diversificadas com produtos da indústria doméstica rural; açougues; produtos da lavoura (feijões, milho); alimentos prontos (quitandas, refeições); animais vivos; leite de vaca; manufaturados (roupas, utensílios domésticos); artesanato regional; produtos do agroextrativismo (frutos, plantas medicinais); pontos fixos (comerciantes estabelecidos no mercado, pouco frequentes nas feiras); mudas e plantas ornamentais; outros (produtos não especificados).

A mesma técnica de classificação foi usada por Ribeiro \& Outros (2004), Ribeiro (2007) e Coêlho (2008), muito útil para orientar a estratificação da amostra de pesquisa porque confere representatividade, em percentual, a categorias de produtos das feiras. Permite, também, que se faça "pesquisa em painel", observando ao longo do tempo a presença de um mesmo feirante ou categoria, possibilitando acompanhar continuidades e rupturas.

Nessa fase a contagem considerou os pontos de vendas ocupados por famílias feirantes e não o número de bancas, pois é comum mais de uma família dividir a mesma banca na feira. Assim, cada ponto de venda representou uma família, porque ser feirante é um ofício associado à família, tanto na produção como nas vendas. Em maio de 2018 os pontos de vendas foram contados, mapeados e classificados por categoria.

Em seguida foram realizadas entrevistas com feirantes, usando questionário semiestruturado, com questões fechadas sobre perfil do feirante, e perguntas abertas sobre 
produção, comercialização e relações com instituições. O questionário foi elaborado, testado, e depois aplicado nas feiras conforme o tempo livre do feirante, de modo a não prejudicar vendas. A parte aberta da entrevista permitiu que o feirante abordasse assuntos que não constavam do roteiro fechado. Foi usada amostragem aleatória estratificada por segmento de produtos, proporcional às categorias mais representativas nas feiras, compreendendo no mínimo 10\% dos feirantes, conforme a Tabela 1 (abaixo) e de acordo com recomendações de autores de referência em metodologia de pesquisa, como Bussab \& Morettin (2004), Bauer \& Gaskell, 2002, e Laville \& Dionne (1999).

Tabela 1: Número de feirantes e amostra pesquisada por município, em números absolutos, vale do Jequitinhonha, 2018.

\begin{tabular}{lcc}
\hline Município & Número de feirantes & Feirantes pesquisados \\
\hline Veredinha & 51 & 10 \\
Turmalina & 178 & 19 \\
Minas Novas & 160 & 20 \\
Itamarandiba & 302 & 36 \\
Chapada do Norte & 45 & 9 \\
\hline Total & $\mathbf{7 3 6}$ & $\mathbf{9 4}$ \\
\hline
\end{tabular}

Fonte: Pesquisa de campo, 2018. Organizada pelos autores, 2019.

A renda gerada na feira foi calculada por estimativa. Os frequentadores foram contados por meio de tarjetas distribuídas na entrada de cada feira. Como nem todos os frequentadores são consumidores, foram contados os consumidores da feira de Turmalina, feira de tamanho médio comparada às outras, cujo mercado municipal tem apenas três saídas que permitiam facilmente observar quem comprava; este percentual de consumidores sobre frequentadores foi tomado como parâmetro. Depois, foi entrevistada aleatoriamente uma amostra de $3 \%$ dos consumidores de cada feira, distribuída proporcionalmente das 6 até as 11 horas. O questionário abordou temas relacionados à renda, gastos e hábitos de consumo. O gasto do conjunto dos consumidores foi usado para estimar a receita dos feirantes, conforme metodologia desenvolvida por Ribeiro (2007).

Em seguida os dados foram organizados e sistematizados, obedecendo a um plano tabular que os dispunha em acordo com as informações fornecidas nas entrevistas. Os dados foram tabulados por município e, em seguida, as informações foram condensadas para os cinco municípios para fins de análise. Os dados singulares de cada município foram usados para devolução de resultados de pesquisa para feirantes e organizações locais de desenvolvimento rural, dando origem a relatório próprio entregue 
e apresentado a cada Associação, Prefeitura e agência de extensão rural, num processo iniciado no município de Itamarandiba em novembro de 2018.

A análise dos resultados consistiu no estudo das informações organizadas e sistematizadas sobre os cinco municípios. Foram usadas como base as questões propostas no roteiro de entrevistas, e a análise estruturada por eixos: a) caracterização dos feirantes; b) sistema de produção; c) formas de comercialização na feira; d) preços, vendas e rendas; e) organização da feira, assistência técnica e sugestões de melhorias.

Por fim, é preciso esclarecer que nem todos os agricultores do Alto Jequitinhonha frequentam a feira livre para vender sua produção. Este artigo privilegia agricultores familiares feirantes - quer dizer: famílias rurais, que vivem em terras próprias, gerem sua produção e vendem parte dela nas feiras livres -, que são a maioria absoluta dos vendedores dessas feiras, que conferem às feiras o caráter rural e que organizam ações em sua defesa. Esses feirantes se definem como agricultores familiares ou "lavradores", termos também empregados pelas organizações que os representam e pelas agências de desenvolvimento rural. Por isso o artigo os adota, e usa com frequência os termos "agricultor familiar feirante" e "agricultor feirante", conforme também fizeram Ribeiro (2007), Coêlho (2008) e Servilha (2008). Denominações equivalentes são usadas na literatura sobre feiras, por autores que tratam deste assunto, tais como Angulo (2002), Anjos, Godoy e Caldas (2005), Alves (2015) e FJP (2017).

\section{Agricultura familiar e feiras}

A agricultura de base familiar ocupa destacada posição econômica e demográfica no espaço rural do Alto Jequitinhonha, onde estabelecimentos da agricultura familiar correspondiam a $88,00 \%$ do total e respondiam por $77,51 \%$ do pessoal ocupado no campo, dispondo de área média de 10 hectares (FJP, 2017; CALDAS, 2018). Embora ocupe porção menor da área rural, a agricultura familiar tem forte presença nas associações e sindicatos, na representação política nos parlamentos municipais e nos conselhos de gestão social. Essa força se manifesta também na sociabilidade, na alimentação e nos costumes, que valorizam o trabalho rural e a relação com a terra. A noção de rural e agricultura familiar disseminada no Alto Jequitinhonha é originada dos vínculos com a terra, com a partilha das glebas por heranças sucessivas, pelo modo de 
reprodução familiar e pela produção autônoma de alimentos, que assegura o consumo doméstico e a renda com o trabalho da família em sua própria terra. Estes valores caracterizam a agricultura familiar do Jequitinhonha. Os conhecimentos tradicionais da sociedade rural dão base para conservação dos ecossistemas e a técnica agrícola adaptada é usada na produção de alimentos de características locais (GALIZONI, 2008; RIBEIRO, 2013; GALIZONI \& OUTROS, 2019).

A importância do conhecimento tradicional, que se manifesta na relação do agricultor com a terra, na organização da produção, no trabalho familiar e nos modos de reproduzir o saber no processo produtivo, foi enfatizada por diversos autores (DIEGUES, 1995; BRANDÃO, 1986; WOORTMANN \& WOORTMANN, 1997; SABOURIN, 2001; PLOEG, 2008; DAYRELL \& OUTROS, 2017). As técnicas materiais, locais e costumeiras que usam o "fazer" como método de transmissão de conhecimentos originam sistemas de produção agroecológicos. Agricultores produzem com base no etnoconhecimento de solos, animais e plantas, na classificação local da natureza e no emprego inteligente dos recursos naturais. No Alto Jequitinhonha a agricultura familiar prima pela autonomia na produção, pela valorização dos saberes e organização peculiar dos sistemas de produção (GALIZONI, 2008; RIBEIRO, 2013).

Transformados em produtos, os elementos da cultura material rural influem na construção da identidade do território; refletem e, ao mesmo tempo, fundamentam as instituições e organizações políticas e econômicas. É por isso que a produção material com as características específicas do território ultrapassa as referências estritamente físiconaturais para se converter num ativo relevante, que potencializa oportunidades, iniciativas e redes territoriais de pequenos negócios. Essa potencialidade, no entanto, não se transforma automaticamente em benefício: carece ser lapidada, construída à medida que a identidade territorial organiza interesses (ABRAMOVAY, 2000; PECQUEUR, 2005).

É neste contexto que se compreende a relação entre a produção agrícola familiar e o abastecimento alimentar das pequenas cidades do Jequitinhonha. Além de produzir alimentos para dar segurança alimentar - abastecer cidadãos em quantidade e qualidade suficientes, conforme Marques (2010) - e suprir necessidades biológicas, aqui se trata também de soberania alimentar, a relação entre agricultura e cultura que une pelo alimento dimensões sociais e econômicas do território, de acordo com Meirelles (2004). 
Por outro lado, o conceito de soberania alimentar associa alimento com a agricultura do local, reforçando as características únicas do produto, associando-o a agroecologia, circuitos curtos de vendas, políticas agrárias e alimentares, e desenvolvimento territorial (MARQUES, 2010).

No Alto Jequitinhonha os produtos das lavouras, da horticultura e das agroindústrias rurais dominam os mercados locais, e a feira livre é o principal ponto de venda desses produtos da agricultura familiar. Na feira as relações pessoais mediam a circulação das mercadorias, criando um fato social que reúne cultura, sociabilidade e comércio. Ribeiro \& Outros (2014) apontaram que, no Jequitinhonha, a venda direta é o canal mais corriqueiro para os produtos elaborados da agricultura familiar, com vendas na comunidade e nas ruas da cidade. Mas é a feira que absorve quase metade da farinha de mandioca $(47,46 \%)$ e da rapadura $(47,59 \%)$, quase dois terços da produção de queijo e requeijão $(61,16 \%)$, quase toda a farinha de milho $(82,14 \%)$. Os dados mostram que, com a exceção de queijo e requeijão que são vendidos com frequência para intermediários, os outros produtos são também para autoconsumo: um terço da produção de farinha de mandioca e da rapadura, quase um quinto da farinha de milho, conforme a tabela 2 , abaixo.

Tabela 2: Destinos de produtos da agroindústria rural no Jequitinhonha, em percentual

\begin{tabular}{lcccc}
\hline $\begin{array}{l}\text { Destino/Canais de } \\
\text { comercialização }\end{array}$ & $\begin{array}{c}\text { Farinha de } \\
\text { mandioca }\end{array}$ & $\begin{array}{c}\text { Farinha de } \\
\text { milho }\end{array}$ & $\begin{array}{c}\text { Queijo e } \\
\text { requeijão }\end{array}$ & Rapadura \\
\hline Venda direta ao consumidor & 47,46 & 82,14 & 61,16 & 47,59 \\
Vendidos para intermediários & 18,93 & 0,00 & 35,32 & 18,98 \\
Outros (indústria, governo, & 0,00 & 0,00 & 0,65 & 0,00 \\
empresas integradoras) & 33,61 & 17,86 & 2,87 & 33,13 \\
Consumidos no estabelecimento & $\mathbf{1 0 0}$ & $\mathbf{1 0 0}$ & $\mathbf{1 0 0}$ & $\mathbf{1 0 0}$ \\
\hline Total & &
\end{tabular}

Fonte: Ribeiro \& Outros (2014).

Org.: Os autores, 2019.

Feiras livres existem há muito tempo no Brasil; o registro mais antigo é de 1687, no estado de São Paulo. Feiras se multiplicaram pelo país, ganharam importância no abastecimento alimentar de centros urbanos, se tornaram espaços em que as relações pessoais superam as dimensões econômicas (ANJOS, GODOY e CALDAS, 2005). O movimento das feiras foi considerado por Coêlho (2008) fato social importante, embora corriqueiro na maioria dos municípios brasileiros; feiras são, também, espaços de integração entre campo e cidade (ANGULO, 2002). À medida que as relações pessoais 
se estreitam, os sujeitos se conhecem pelo nome, pelo gosto, pelo que trocam, numa dinâmica diversa da compra em supermercados, por exemplo, em que o consumidor escolhe o produto na prateleira sem negociação (SERVILHA, 2008).

Araújo \& Ribeiro (2018) observaram que, no Brasil, a maioria dos estudos sobre feiras livres foram feitos no Nordeste. Foi nesta região que Palmeira (2014) observou a segmentação do espaço das feiras livres, com divisões por produtos em setores delimitados: feijões, carnes, farinhas, verduras. Para Palmeira, o preço estabelecia a divisão entre setores; no entanto, nos setores onde era maior a variação de preços circulava maior número de vendedores. Garcia (1983; 1992), analisando igualmente casos no Nordeste, registrou que a feira articulava grupos sociais diversos e que, embora o espaço fosse predominantemente masculino, o crescimento da presença das mulheres punha em questão a força da divisão sexual do trabalho. Também Héredia (1979), que estudou a relação produção-consumo-venda na agricultura familiar nordestina, notou que o cálculo econômico orientava o agricultor/produtor na venda e no dimensionamento dos estoques de alimentos, de modo que a família produzia a maior parte dos alimentos que consumia; mas como não produzia todos, a feira era vital para a reprodução por permitir trocas de alimentos por dinheiro, que seria convertido em alimentos não produzidos.

As feiras livres do vale do Jequitinhonha são estudadas desde começos da década de 2000. Estudo pioneiro foi feito por Angulo (2002), analisando as relações sociais na feira livre de Turmalina; em 2003 Ribeiro \& Outros (2004) dimensionaram vendas, frequência e rendas na feira de Minas Novas. Noutro estudo, de 2005, foram analisadas as feiras livres dos municípios de Berilo, Virgem da Lapa, Carbonita, Veredinha e Francisco Badaró (RIBEIRO, 2007), investigando as relações entre a feira e a economia local: abastecimento, vendas e geração de renda para o agricultor. Servilha (2008) analisou as relações socioculturais, focando nas trocas materiais e simbólicas do mercado de Araçuaí; Alves (2015) analisou as feiras de Itamarandiba, Carbonita, Aricanduva e Turmalina a partir das narrativas dos feirantes; Araújo \& Ribeiro (2018) analisaram os destinos dos excedentes de feiras do Jequitinhonha.

Estudos sobre as feiras do Jequitinhonha enfatizaram sua importância para o abastecimento e a economia dos municípios, a relevância das características culturais e sociais, e seus vínculos com as especificidades ambientais. Além disso, investigaram a 
relação do agricultor familiar feirante com a terra, as técnicas que utilizam para negociar a produção na feira, sua renda, o perfil do consumidor e as relações desencadeadas pela dinâmica das feiras. Uma característica relevante da maior parte dos estudos foi a cooperação com organizações de base de agricultores familiares e feirantes do Jequitinhonha. Incorporando seus resultados à ação pública, os trabalhos orientaram ações em apoio às feiras livres do Território. Assim, prefeituras municipais, sindicatos de trabalhadores rurais, agências de extensão rural e, principalmente, o Centro de Agricultura Alternativa Vicente Nica enfrentam os desafios da feira livre e da comercialização, buscando melhorias na produção e organização dos agricultores feirantes por meio da parceria entre instituições.

Entre as atividades destaca-se o Programa de Apoio às Feiras Livres, coordenado pelo $\mathrm{CAV}$, que conduz ações em pesquisas, capacitações, fundo rotativo, extensão rural e valorização da produção feirante. Para isso, desde 2005 promove anualmente o "Seminário de Feiras Livres e Políticas Públicas do Vale do Jequitinhonha", evento itinerante com afluxo de agricultores, técnicos, agências de desenvolvimento rural, instituições estatais e da sociedade civil do Jequitinhonha. A diversidade do público do evento contribuiu para ampliar o escopo das discussões sobre feiras, estimular as trocas de experiências nos grupos de trabalhos formados pelos diferentes setores que têm relações com as feiras - feirantes, poder público, ATER, agências de desenvolvimento e pesquisadores. Assim, estudos sobre feiras livres no Brasil e, em especial, no Jequitinhonha mineiro, permitiram reflexões importantes sobre a comercialização da agricultura familiar neste canal de venda direta.

\section{A área de estudo}

O vale do Jequitinhonha está situado a nordeste do estado de Minas Gerais; dividido em 59 municípios distribuídos em área equivalente a 14,5\% do estado. Para efeito de programas públicos o Jequitinhonha mineiro é subdividido em três territórios delimitados pelo extinto Ministério de Desenvolvimento Agrário (MDA), no âmbito do Programa Nacional de Desenvolvimento Sustentável de Territórios Rurais - PRONAT: Alto, Médio e Baixo Jequitinhonha. Para planejamento, o governo de Minas Gerais dividiu o Jequitinhonha em dois Territórios: Alto e Médio/Baixo (FJP, 2017). 
O Alto Jequitinhonha fica no domínio do Cerrado, com vasta cobertura vegetal nativa conservada pelo manejo comunitário da população rural, que usa técnicas adaptadas e criou, ao longo de gerações, formas costumeiras de organização que regulam o acesso aos recursos naturais usados em comum - terra, água, plantas. Unidades de produção são domínios privados da família; mas famílias, reunidas em comunidade, compartilham partes de chapadas e campos mantidas em domínio comunitário, onde criam animais, colhem frutos nativos, plantas medicinais e lenha. Mesmo depois da privatização de grande parte das áreas comuns com a implantação da monocultura de eucalipto na década de 1970 , a relação entre população e natureza é pautada pelos costumes, pelo conhecimento local, e pela identidade que fundamenta o pertencimento ao território (GALIZONI, 2008; RIBEIRO, 2013; SANTOS, 2016).

Este estudo analisou feiras livres de cinco municípios do Alto Jequitinhonha: Chapada do Norte, Itamarandiba, Minas Novas, Turmalina e Veredinha, conforme a Figura 1, a seguir.

Figura 1-Área de estudo no Alto Jequitinhonha - Minas Gerais (2018)

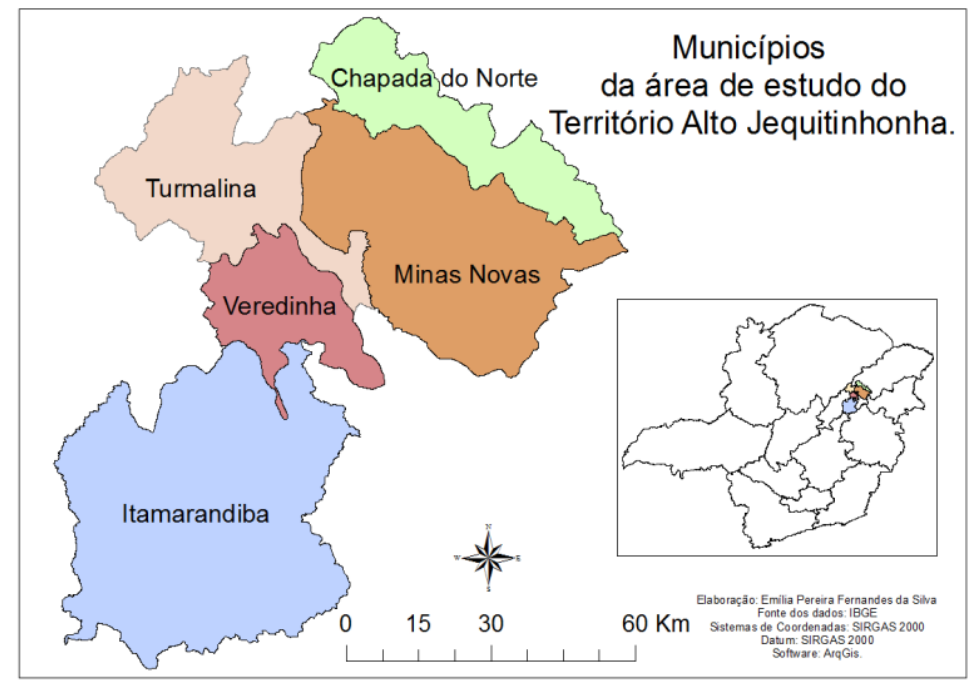

Fonte: elaborado por Emília P. Fernandes em 2018com base em dados do IBGE. Datum SIRGAS: 2000. Org.: os autores, 2019.

Os municípios estudados têm características similares em termos de bioma, paisagem, história, demografia, regimes agrários, distribuição fundiária e atividade econômica; no entanto, conservam particularidades de pauta produtiva e organização social. O município de Chapada do Norte foi alocado pelo extinto MDA no Território do 
Médio Jequitinhonha; mas enquanto durou o programa reivindicou seu pertencimento ao Alto Jequitinhonha.

Dados do Censo Demográfico do IBGE de 2010 indicam que a população desses municípios totalizava 101.762 habitantes; destes, 55,97\% eram população urbana e $44,03 \%$ população rural, percentual bastante elevado quando comparado à média de $14,71 \%$ de população rural de Minas Gerais (CALDAS, 2018) e 15,64\% de população rural do Brasil (IBGE, 2010). Os dados da Tabela 3, a seguir, indicam que Itamarandiba, Turmalina e Veredinha apresentavam população urbana maior que a população rural, que Itamarandiba e Minas Novas contavam com população total maior, e que Veredinha era o município menos populoso.

Tabela 3: Dados demográficos dos municípios estudados no Alto Jequitinhonha, Minas Gerais (2010)

\begin{tabular}{lccc}
\hline \multicolumn{1}{c}{ Municípios } & População urbana & População rural & População total \\
\hline Chapada do Norte & 5.694 & 9.495 & 15.189 \\
Itamarandiba & 21.988 & 10.187 & 32.175 \\
Minas Novas & 12.584 & 18.210 & 30.794 \\
Turmalina & 12.926 & 5.129 & 18.055 \\
Veredinha & 3.769 & 1.780 & 5.549 \\
\hline Total & $\mathbf{5 6 . 9 3 1}$ & $\mathbf{4 4 . 8 0 1}$ & $\mathbf{1 0 1 . 7 6 2}$ \\
\hline \multicolumn{2}{c}{ Fonte: IBGE, Censo Demográfico de 2010. Org.: Os autores, 2019. }
\end{tabular}

Nesses municípios os setores de atividade econômica mais representativos eram serviços, agropecuária e indústria, nesta ordem. Serviços respondiam por $68,5 \%$ do Valor Adicionado Bruto (VAB), incluindo administração pública, comércio, construção civil, imóveis, aluguéis e prestação de serviços; agropecuária respondia por 19,4\% do VAB, compreendendo agricultura, silvicultura e exploração vegetal - essa média no estado era de $6,4 \%$; indústria respondia por $12,1 \%$, incluindo principalmente extração mineral, alimentos e bebidas, e produtos têxteis (FJP, 2017).

A origem comum dessa área do Alto Jequitinhonha é o município de Minas Novas, cuja fundação remonta ao século XVIII e ao denominado "ciclo do ouro". Os municípios distam entre 20 a 25 quilômetros um do outro, o que facilita a mobilidade dos moradores entre eles, por motivos como acesso à saúde, educação, trabalho, compras, lazer e serviços diversos. Turmalina, Veredinha, Minas Novas e Chapada do Norte têm características semelhantes de clima, solo e pauta produtiva. Pode-se afirmar que moradores de Chapada 
do Norte frequentam mais Minas Novas, e que a população de Veredinha procura por serviços em Turmalina. Isto ocorre por conta da proximidade, da origem comum de antigos distritos, e da hierarquia de serviços, que são mais especializados nas cidades maiores. Já Itamarandiba, com centro urbano mais populoso, além de dispor de rede de serviços própria e mais complexa, também difere um pouco dos outros municípios por estar situado, como dizem os moradores, bem na "entrada da mata”, ou seja: na transição de Cerrado para Mata Atlântica, portanto mais chuvoso, com terras naturalmente mais férteis e, principalmente, com a grande biodiversidade característica de encontro de biomas que se reflete na diversidade de produtos que os agricultores familiares oferecem nas feiras.

\section{Feiras no Alto Jequitinhonha}

Cada feira municipal tem organização peculiar, que resulta dos arranjos feitos entre feirantes e prefeitura municipal. Todos os municípios têm Associação de Feirantes, com exceção de Itamarandiba, onde o Sindicato de Trabalhadores cumpre parcialmente a função; a representação dos feirantes zela pelo acesso livre, pelo controle de entrada de produção de outros municípios, pela organização das demandas de feirantes e, em parte, pela comercialização dos excedentes de feira.

O poder público municipal responde por parte do sucesso das feiras. Os mercados são zelados pelas prefeituras municipais para o bom funcionamento; em todos os municípios pesquisados a municipalidade responde pela organização, manutenção, limpeza e bancas. No entanto, cada município tem sua particularidade na organização do transporte, que é muito importante para a frequência regular do feirante; às vezes uma comunidade rural tem transporte toda semana, outra a cada quinze dias, conforme o circuito determinado pela prefeitura. Mas, sempre, algumas comunidades não têm o transporte, seja pelo número pequeno de feirantes, pela distância ou por dificuldades da logística, e os agricultores feirantes dessas comunidades se resolvem como podem. As prefeituras municipais coíbem a presença de produtores de outros municípios, e nisso são apoiadas, mas também cobradas, pelos feirantes, por associações e sindicatos.

A participação na feira é livre, bem entendido: para produtores do município que respeitem os pontos de vendas alheios e sigam os preceitos de bom comportamento evitem brigas, excessos de álcool, disputas com outros feirantes. Cada família feirante 
dispõe de um ponto de venda no espaço da feira, isento de pagamento de taxas ou licença para vender.

Feiras acontecem nos mercados, prédios próprios que ficam localizados no centro das cidades, e sempre aos sábados. Quanto às dimensões, a feira de Itamarandiba pode ser considerada grande; com mais de 300 pontos de vendas, se equipara às maiores do vale do Jequitinhonha: Capelinha, Almenara, Araçuaí e Padre Paraíso. As feiras de Minas Novas e Turmalina são de porte médio, entre 150 e 200 feirantes, e as feiras de Chapada do Norte e Veredinha podem ser consideradas, em termos relativos, como pequenas, com média de 50 feirantes. No entanto, é importante ponderar que há flutuação no número de feirantes, por falta ou pouca quantidade de produtos em determinada semana ou época do ano, pelas condições de acesso à cidade, por falta de transporte ou pelas condições da estrada no tempo das chuvas.

Abaixo são apresentadas descrição e imagens dessas feiras, por município.

\section{Feira livre de Chapada do Norte}

O mercado de Chapada do Norte é um prédio municipal apropriado, mas que nos dias de feira não comporta as 45 famílias feirantes, cabendo 19 pontos de vendas dentro do mercado; do lado de fora, na rua, ficam outros 26 pontos. À venda encontram-se diversos tipos de produtos, verduras, produtos artesanais (rapadura, farinha de mandioca, farinha de milho, queijo, açúcar mascavo, melaço, doces, biscoitos e pães caseiros, entre outros), produtos da lavoura, bancas de carne suína, alimentos prontos (bolos, biscoitos e café servido na hora), e bancas de produtos manufaturados (panelas, vasilhames e entre outros itens).

Figura 2: Croqui da feira (1), bancas de feirantes (2) - (2017)

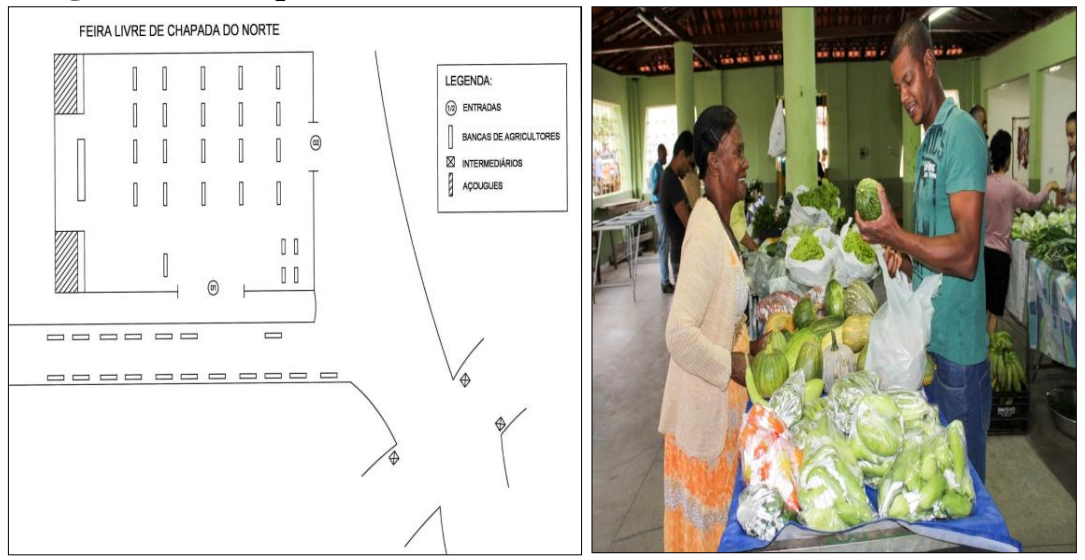

Fonte: croqui elaborado por Sirlene Cruz e Arida Chagas, 2018. Foto: acervo do CAV, 2017. 


\section{Feira livre de Minas Novas}

A feira de Minas Novas ocorre no mercado municipal, mas grande número de feirantes vendem na rua em frente ao mercado. A Prefeitura Municipal oferece transporte gratuito para os feirantes, mas alguns costumam ir por conta própria. Em algumas comunidades o transporte é oferecido a cada quinze dias, e isto influi no cenário na feira, que às vezes fica mais vazia ou mais cheia. Totaliza 160 pontos de vendas, 63 pontos ficam dentro do mercado e 97 pontos se concentram na rua. Faltam bancas de venda, e 55 pontos oferecem seus produtos no chão da rua em cima de lonas, balaios, sacos, caixas de couro.

Figura 3: Croqui da feira (1), feirante de Minas Novas (2) - (2018)

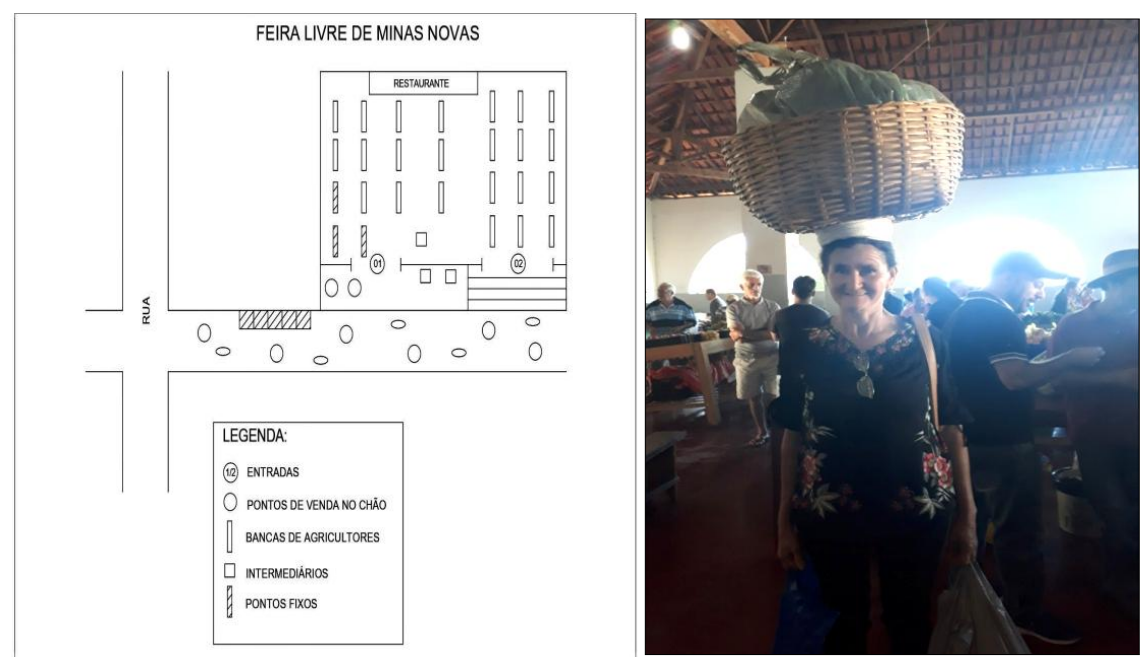

Fonte: croqui elaborado por Sirlene Cruz e Arida Chagas, 2018. Acervo Sirlene Cruz, 2018.

\section{Feira livre de Turmalina}

A feira de Turmalina é uma das poucas que comporta todos os feirantes na área interna do mercado municipal. As bancas são organizadas por setores, conforme diferentes tipos de produtos, e totalizavam em 2018, 178 pontos de vendas: carnes, alimentação pronta, abrigo para aves; ao fundo do mercado vende-se fumo, produtos do agroextrativismo e, ainda, uma banca oferece livros que podem ser emprestados. Na parte central do mercado as bancas vendem produtos da indústria doméstica rural, da lavoura e verduras; um ponto vende artesanato das associações de artesãs do município. 
Figura 4: Croqui da feira (1), área do mercado (2) - (2018)

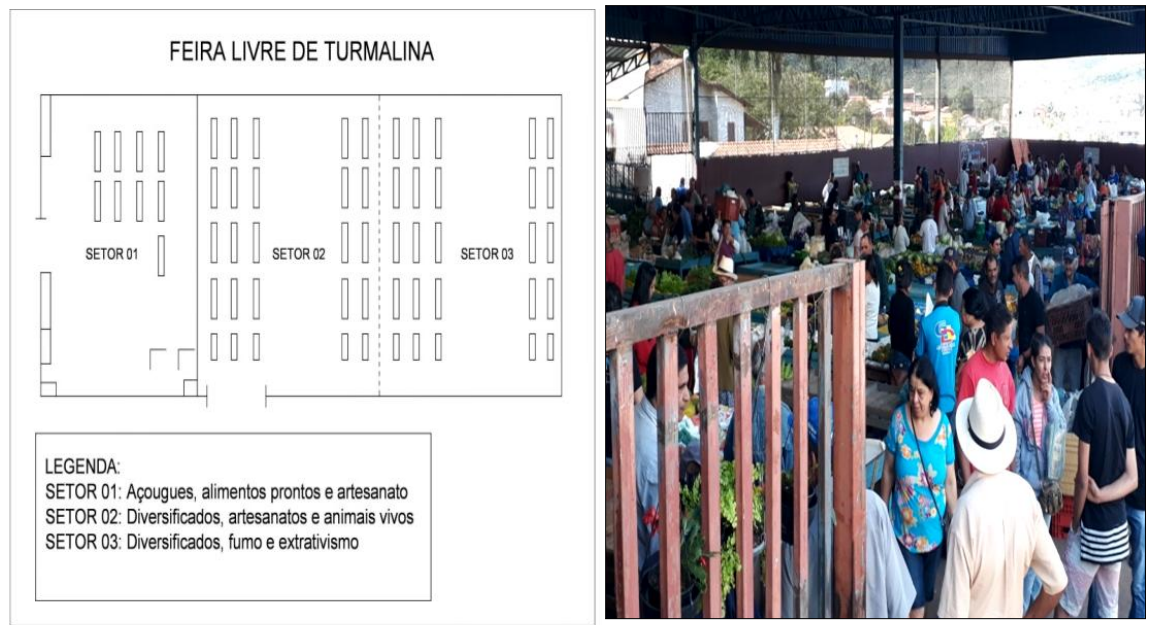

Fonte: croqui elaborado por Sirlene Cruz e Arida Chagas, 2018. Acervo Sirlene Cruz, 2018.

\section{Feira livre de Veredinha}

Em Veredinha, numa solução criativa, a feira é realizada no espaço de uma quadra poliesportiva coberta que comporta os 51 feirantes habituais. As bancas são organizadas pela Prefeitura, que também disponibiliza transporte gratuito para feirantes. Nessa feira há um espaço reservado para depósito que guarda pelo tempo necessário alimentos não perecíveis que excedem das vendas, e foi criado um sistema próprio do município para compras de funcionários da Prefeitura.

Figura 5: Croqui da feira (1), produtos diversificados na feira (2) - 2018

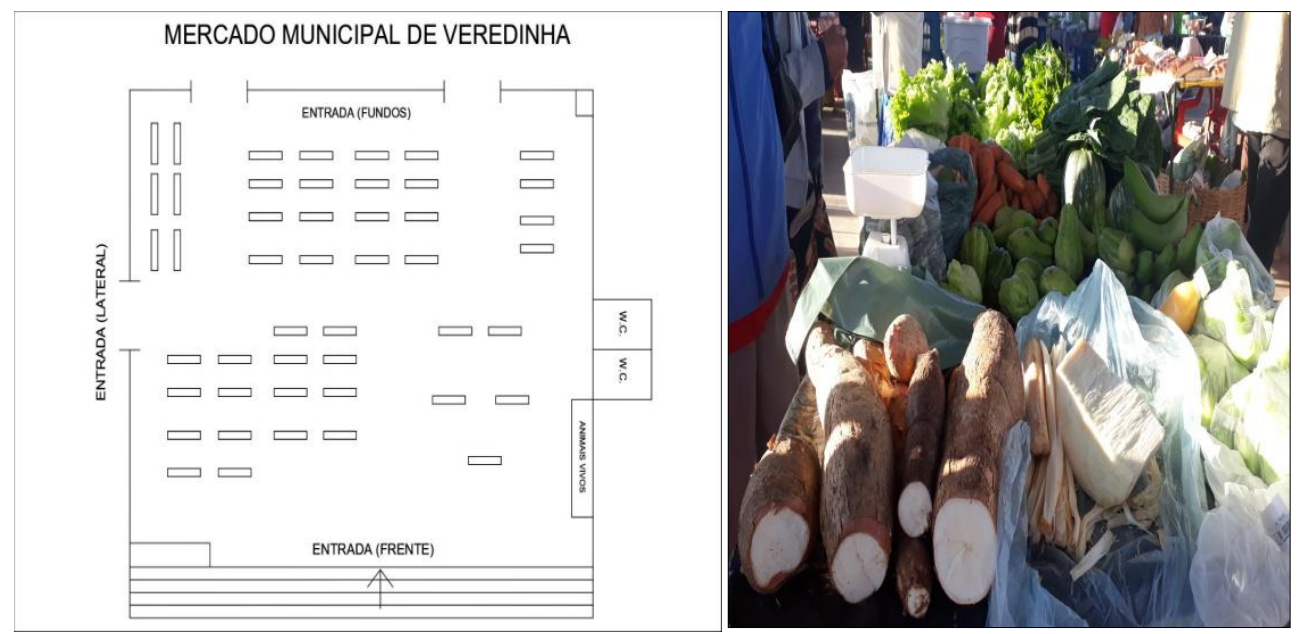

Fonte: croqui elaborado por Sirlene Cruz e Arida Chagas, 2018. Acervo Sirlene Cruz, 2018. 


\section{Feira livre de Itamarandiba}

A feira de Itamarandiba, além de ocupar todo o espaço do mercado municipal, transborda para a praça externa, área coberta que abriga 78 pontos. $\mathrm{O}$ mercado tem dezoito entradas, sendo oito pela frente, e outras dez entradas pelas laterais. O fluxo de produtos e pessoas é intenso aos sábados: além dos feirantes, em média 5 mil consumidores frequentam este local.

Figura 6: Croqui da feira (1), vista interna do mercado (2) - (2018)

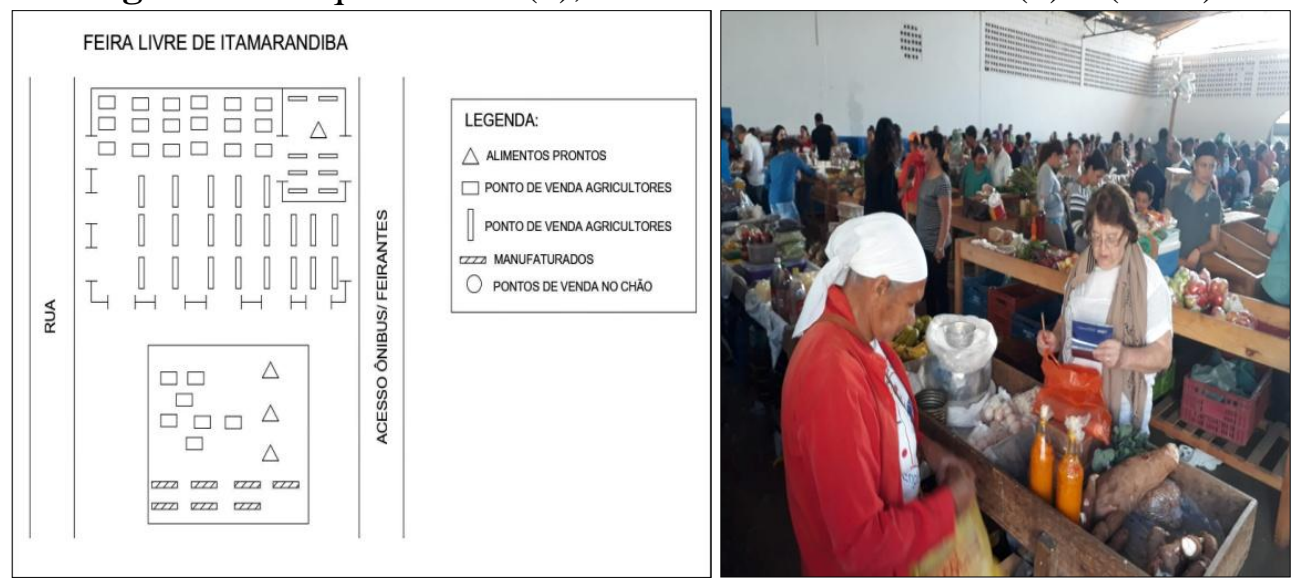

Fonte: croqui elaborado por Sirlene Cruz e Arida Chagas, 2018. Acervo Sirlene Cruz, 2018.

Mercados situados no centro das cidades facilitam o acesso e permitem que número maior de pessoas frequente as feiras. Também, e não menos importante, a localização central favorece as compras que agricultores feirantes fazem no comércio e beneficia comerciantes, que vêm seus estabelecimentos mais concorridos aos sábados.

As feiras agitam o centro dessas cidades. Começam muito antes do amanhecer, por volta de quatro e meia da manhã, quando já acontecem movimentos da organização das bancas, chegam feirantes carregados de balaios e sacos de mercadorias para arrumar produtos nas bancas. Há, também, consumidores que preferem chegar cedo à feira para escolher produtos que consideram melhores; mas é por volta das seis horas da manhã que a maioria dos feirantes chega das comunidades rurais mais distantes e consumidores afluem em grande quantidade; daí em diante, até por volta das nove horas, cresce o movimento de pessoas e produtos.

À primeira vista o espaço da feira parece confuso: corredores entre bancas ficam apertados com a quantidade de pessoas circulando, examinando produtos, negociando. 
Há barulho, conversas misturadas, mas ninguém grita para divulgar sua mercadoria; só, às vezes, um mascate se aproveita do movimento para apregoar manufaturados.

Nesses municípios as feiras começaram acontecer de forma dispersa e autônoma, pelas ruas da cidade; com o tempo se consolidaram, motivaram o poder público a delimitar o espaço em resposta às demandas de feirantes e consumidores. No espaço da feira qualquer produtor pode vender, e há entre eles um espírito de corpo muito forte, que atua em defesa da autonomia do feirante, na discriminação de intermediários e "marreteiros" - vendedores que vão à feira vender grandes lotes de produtos "de fora". ${ }^{2}$

Feirantes também costumam cobrar ações das prefeituras. Prefeitos e vereadores costumam dizer que feira "não dá voto, mas tira voto", conforme dizia Ademar dos Santos, vereador; ou seja: feirantes e consumidores consideram que ações em favor da feira são obrigações dos governantes, portanto não merecem retribuição em votos; mas a falta de ação compromete a receita de uns e a pauta alimentar de outros.

Várias ações do setor público, além do cuidado com o mercado, são importantes para as feiras: a manutenção das estradas que ligam o campo às cidades, a extensão rural para os produtores, o suporte em mecanização agrícola, os sistemas institucionais de compras de produção excedente e, sobretudo, a valorização das feiras e o incentivo para a população consumir produção do município. Esta última iniciativa, desde os anos 2000, é conduzida por parcerias entre prefeituras, associações de feirantes e CAV.

Certo é que, ao longo do tempo, as feiras livres se mantêm estáveis: em praticamente duas décadas variou em $2 \%$ o número de feirantes nesses municípios, um percentual insignificante quando se pondera as razões que influem para ausência de feirantes: transportes, estradas, secas....

A Tabela 4 mostra que ocorreu acréscimo no número de feirantes de Minas Novas, que saltou de 133 (2004) para 160 (2018); nos municípios de Chapada do Norte, Itamarandiba, Turmalina e Veredinha o número de feirantes em 2018 diminuiu em relação às pesquisas anteriores, mas o quadro é estável no longo prazo.

\footnotetext{
${ }^{2} \mathrm{O}$ desentendimento entre feirantes do lugar e vendedores de fora se deve ao fato destes geralmente venderem grandes partidas de produtos comprados no atacado a preço mais baixo e com qualidade também inferior; estes vendedores denominados como "marreteiros" pelos feirantes do Jequitinhonha foram analisados nessas feiras por autores como Angulo (2002) e Ribeiro (2007); Garcia (1983) e Araújo e Ribeiro (2018) também fizeram referência a esses personagens.
} 
Tabela 4: Evolução do número de feirantes nos municípios pesquisados do Alto Jequitinhonha (2004-2018)

\begin{tabular}{lcc}
\hline \multirow{2}{*}{ Município } & \multicolumn{3}{c}{ Feirantes } \\
\cline { 2 - 3 } & Linhas de base (2004, 2007, 2009 e 2015) & $\mathbf{2 0 1 8}$ \\
\hline Chapada do Norte & 41 & 45 \\
Itamarandiba & 335 & 302 \\
Minas Novas & 133 & 160 \\
Turmalina & 188 & 178 \\
Veredinha & 53 & 51 \\
\hline Total & $\mathbf{7 5 0}$ & $\mathbf{7 3 6}$
\end{tabular}

Fontes: Pesquisa de campo, 2018; linhas de base: Ribeiro \& Outros (2004) para Minas Novas; Ribeiro (2007) para Veredinha; ICA/UFMG (2015) para Chapada do Norte; CNPq (2012) para Itamarandiba. Org.: Os autores, 2019.

\section{Feirantes}

Feira, dizem os agricultores feirantes do Jequitinhonha, é "cálculo". Por cálculo entendem duas capacidades diferentes. Uma, constante: a capacidade de cumprir um planejamento rigoroso, que vai da lavoura ao produto final, para criar o produto "caprichado" que expõem nas feiras. Outra, cumulativa: a sabedoria sobre o negócio, a informação que orienta a entrada na trama complexa do comércio, que passa pela gestão eficiente da força de trabalho, dos custos e, sobretudo, da negociação com fregueses. Por isso, fazer negócio é sinônimo, no linguajar dos agricultores, de "fazer trama" - misturar bens e pessoas - e de "cortar trama" - ter esperteza suficiente para evitar ser embromado nas trocas.

Ser feirante é mais que uma ocupação semanal: é um ofício; mas, serve apenas para aqueles agricultores que "têm cabeça" para negócios. Se a "cabeça não ajuda o negócio desanda", afirmava Boaventura de Castro, de Turmalina, que assessora feiras livres. Pelo visto, muitos agricultores do Alto Jequitinhonha têm boa cabeça, e a qualidade é hereditária, porque em alguns casos o ofício já ocupa gerações de pessoas da mesma família. Muitos feirantes dizem que "desde cedo", ainda crianças, acompanharam os pais na feira, e assim aprenderam o ofício e passaram a vender na feira. Feirante de Itamarandiba, Dona Justina Aparecida disse que, depois de tantos anos, nem sabia há quanto tempo cumpria esse ofício, que se incorporou à sua vida: "Quando eu não posso vir, as pessoas sentem minha falta. Aqui, somos uma família." A feira, para ela, é um lugar de negociar, mas também de estreitar laços com pessoas - Mateus Servilha (2008) já havia observado isso em outra feira. Os ganhos, em negócios e relações, justificam os 
esforços dos corpos: passar a semana selecionando a produção mais "caprichada", gastar a sexta-feira montando fardos, sair nas madrugadas dos sábados carregando a produção em animais ou nas costas até o ponto de baldeio, enfrentar o balanço do caminhão feirante por quilômetros - a maior parte dos feirantes mora a mais de 20 quilômetros de distância da cidade -, para chegar à feira antes do dia amanhecer. "A gente traz o que dá para carregar. Nem sempre as estradas são boas, e isso dificulta trazer mais quantidade de mercadoria para a feira", assim dizia o Senhor João Catulo, feirante de Turmalina. Usam meios de transporte que variam de acordo com a condição de cada um. Carro próprio, motos, alguns usam animais ou "ônibus de linha", mas usam com mais frequência mesmo é o ônibus ou caminhão de feirante, fornecido pela Prefeitura, pois nem sempre as vendas da feira cobrem os custos do transporte próprio.

Tanto esforço, por tantos anos, cria certos direitos costumeiros. Feirantes se consideram um grupo, e como grupo defendem seus direitos, barram entrada de atacadistas e vendedores de outros municípios, se manifestam a favor das suas normas próprias de negócios, sobre a organização do espaço de vendas, contra e a favor de medidas do poder público.

A forte presença da agricultura familiar é uma característica das feiras no Alto Jequitinhonha. Nos municípios pesquisados apenas 7,45\% dos feirantes vivem nas cidades: são açougueiros, vendedores de manufaturados e de comida pronta; 92,55\% dos feirantes são agricultores familiares que vivem em comunidades rurais. Combinando dados do Censo Agropecuário de 2006 (IBGE, 2006) e do percentual de agricultores nas feiras é possível afirmar que 2,39\% dos agricultores familiares do município participam da feira de Chapada do Norte; este percentual alcança 17,18\% em Itamarandiba, 5,77\% em Minas Novas, 19,28\% em Turmalina e 8,54\% em Veredinha. A participação desigual de agricultores nas feiras se deve aos programas de incentivo de cada município, às dimensões do mercado consumidor e a fatores como água, clima, rodovias e distâncias da sede do município.

Dois terços dos feirantes desses municípios têm idade acima de 46 anos, e o número de feirantes jovens é bastante reduzido. Há uma relação direta entre perfil etário e escolaridade; a maioria dos feirantes frequentou escola até a $4^{\mathrm{a}}$ série do antigo primário; $10 \%$ deles não dominam a leitura. 
Os dados da pesquisa revelaram que $80,85 \%$ dos agricultores feirantes produzem em terrenos próprios, normalmente glebas herdadas que giram em torno de 10 hectares, o tamanho do sítio de 51,32\% dos entrevistados. Essas áreas geralmente compreendem parte de "terras de cultura", consideradas próprias para lavouras, mas pelo menos a terça parte costuma ser "terra de campo", áreas pedregosas, pouco férteis. Além disso, com as secas recorrentes que marcaram o período 2011 a 2018, estava difícil cultivar lavouras anuais de feijão, arroz e milho, que dependem de chuvas regulares. A seca prolongada contribuiu para reduzir cultivos, e isso afetou o consumo familiar, a criação de animais e também a oferta de produtos nas feiras livres. Assim, contraditoriamente, do ponto de vista dos feirantes as feiras ficaram mais importantes, por se tornarem condição para obter receitas para adquirir alimentos essenciais, principalmente feijão para consumo humano e milho para alimentação animal. Falta de produtos da lavoura representa despesa maior e receita menor, por isso os feirantes fazem lavouras com frequência regular; perdem plantios, e investem em cultivos resistentes como cana-de-açúcar, ou hortas irrigadas e indústria doméstica rural. Com a irrigação e o processamento agroindustrial são forçados a gastar mais água numa situação de escassez.

Água, efetivamente, é um grande problema: 40,43\% dos agricultores feirantes informaram que enfrentam algum tipo de dificuldade de abastecimento em suas unidades de produção. E falta d'água afeta também a produção, conforme indicaram 37,23\% deles, que reclamaram da pouca água, de nascentes e córregos secos, e da necessidade frequente do caminhão-pipa para abastecimento.

Feirantes adotam três sistemas de lavoura: a) sistema tradicional, que dispensa uso de máquinas, veneno e adubo químico, adotado por 30,86\% deles; b) sistema mecanizado, que usa tratores, arados e grades para preparo do solo, utilizado por 23,40\% deles; e c) sistema misto, combinando técnicas tradicionais e mecanização para preparo da terra, adotado pela maioria, 41,49\% dos agricultores; 4,25\% dos feirantes não faziam lavouras. O conhecimento tradicional é muito importante no cultivo; ainda que haja emprego combinado do cultivo tradicional com máquinas, são usados métodos de produção que potencializam o conhecimento costumeiro sobre solos, plantas nativas e adubos orgânicos; economizam energia e água, e, não por acaso, criam produtos considerados "limpos" pelos compradores nas feiras. 
A cultura material do território e a relação direta do feirante com sua freguesia influenciam nas práticas agrícolas. Clientes querem alimentos sem veneno, que usam técnicas tradicionais. Feirantes preferem adubos orgânicos e 50\% deles compram esterco de bovinos ou aves para suprir a produção. Adubos químicos são adotados por 41,48\% dos agricultores entrevistados. Também, 76,59\% dos feirantes entrevistados compram sementes. Já o uso de veneno na produção é raro: $12,77 \%$ informaram precisar usar veneno em algumas situações; no entanto, talvez seja preciso relativizar esse dado, porque nem sempre é fácil obter este tipo de informação.

Nos municípios pesquisados, os serviços de assistência técnica e extensão rural provêm da Emater, das prefeituras municipais, do CAV e de associações comunitárias ou de feirantes. Porém, $65,96 \%$ dos agricultores feirantes afirmaram não receber assistência técnica. Dados de pesquisa semelhante no Jequitinhonha, no ano de 2005, revelaram que $75 \%$ dos feirantes não recebiam assistência técnica (RIBEIRO, 2007). Aqui também é preciso relativizar o dado, porque o conceito de acesso à assistência técnica e, principalmente, à extensão rural, abre margem para dúvidas. Depende do entendimento subjetivo que o agricultor tem por assistência técnica, e muitos deles consideram como equivalente à presença constante do técnico acompanhando a produção, e isso definitivamente está fora do escopo de todas as agências de assessoria ao produtor. A participação dos agricultores feirantes em cursos de capacitação voltados para produção, vendas e associativismo é pouca expressiva: menos de $50 \%$ deles.

\section{Produtos e vendas}

Varia a diversidade de produtos nas feiras livres do Alto Jequitinhonha de acordo com o "tempo da seca" e o "tempo das águas"; variam tipo, quantidade e frescor da produção. Esta pesquisa, feita no tempo da seca de 2018, identificou 736 pontos de vendas nas feiras livres nos cinco municípios estudados.

O levantamento dos tipos de produtos na feira constatou que $39,13 \%$ das bancas ofertavam produtos diversificados, compreendendo verduras, grãos e frutas na mesma banca. Já as bancas mistas de produtos diversificados com produtos da indústria doméstica rural respondiam por $26,49 \%$ do total de bancas existentes nas feiras pesquisadas. Juntas, as duas categorias representavam $65,62 \%$ dos pontos de vendas e indicavam característica 
da agricultura familiar do Jequitinhonha: a diversificação da produção. As demais categorias de produtos foram: indústria doméstica rural (9,51\%); frutas, legumes e verduras $(6,11 \%)$; carnes $(2,85 \%)$; alimentos prontos $(3,40 \%)$; produtos manufaturados $(4,62 \%)$; animais vivos $(1,77 \%)$; artesanato regional $(1,22 \%)$; produtos do extrativismo $(0,41 \%)$; produtos da lavoura $(0,95 \%)$; pontos fixos,que vendem durante toda a semana $(1,49 \%)$; mudas e plantas ornamentais(1,09\%); e outros tipos de produtos $(0,96 \%)$.

Feirantes sempre organizam sua participação na feira em função do que dispõem, e a variedade da oferta revela que combinam produtos para sempre dispor do que ofertar: verduras com doce de leite, frutas e rapadura, farinha de milho e ovos. Prova isso o percentual baixo de feirantes expondo apenas um produto: 9,51\% vendiam apenas produtos da agroindústria; $6,11 \%$ vendiam apenas frutas, legumes e verduras.

Mas, quaisquer que sejam os produtos, são em grande parte originários de própria produção, da "labuta" da família em seu terreno: 78,02\% dos feirantes vendem apenas produção da família, 20,88\% combinam produção própria com itens da produção alheia. E produção alheia, aqui, não é produção intermediada; quase sempre o feirante regular que tem tino para negócio, vai sempre à cidade transportando balaios e caixas - leva também produtos de parente ou vizinho para vender, e nem sempre recebe participação na venda. Em alguns casos, poucos, o feirante compra de quem produz para revender junto com seu produto, e essa negociação pode ocorrer até na própria feira. Por fim, um percentual insignificante de feirantes, $1,10 \%$, vende apenas itens da produção alheia. Assim se compreende a aversão desses feirantes por intermediários e a justificada defesa que as prefeituras fazem da feira como espaço exclusivo da agricultura familiar do município, que dá conta de abastecer a cidade com sua produção.

Normalmente o feirante sabe a quantidade média que costuma vender num sábado. Em começos de mês vende mais porque os moradores da cidade receberam salários, aposentadorias e bolsas, em fins de ano vende mais porque pessoas que moram fora parentes, migrantes - vêm passar as "festas" no município.

O preço é formado de acordo com "o preço que corre na feira", como já havia sido observado por Angulo (2002; p. 55). A determinação de preços surge das conversas entre feirantes, que tomam como base o preço da semana passada, analisam a safra, a demanda, e formam juntos o preço que "correrá". Mas esse preço varia conforme a época do ano; 
por exemplo, a safra de produtos da indústria doméstica é na seca, e os produtores que têm variedades precoces de mandioca entram mais cedo e com melhor preço no mercado. E os preços variam também conforme o andamento da feira, principalmente de produtos perecíveis, que vão caindo de preço à medida que avançam as horas da manhã, caindo muito depois das 9 horas, quase sempre acompanhando a queda de qualidade e o aumento do risco de sobrar.

Vendas nas feiras são feitas geralmente à vista. Embora existam feirantes que também vendem a prazo ou fiado, as vendas à vista propiciam receita líquida toda semana. Assim, a feira irriga a economia rural e esta irriga a economia urbana, já que parte do dinheiro que circula na feira é gasto com a "despesa" da casa, em supermercados, com artigos que não são produzidos no terreno. Mas compram também em farmácias, açougues, padarias, casas agropecuárias. Conforme já notaram outros autores (HERÉDIA, 1979; GARCIA 1983; RIBEIRO, 2007), a feira é também um meio de adquirir dinheiro para comprar itens de consumo que faltam. Comerciantes das cidades louvam os feirantes como fregueses, e acreditam que feiras semanais e aposentadorias mensais sustentam boa parte do comércio urbano.

Para os feirantes, que costumam vender para comprar, as receitas à vista da feira são fundamentais para o sustento, embora possam dispor de outras fontes. Muitos são aposentados: 28,72\% deles. Costumam ter fontes diversas de renda, que vêm das vendas de produtos a supermercados, na rua ou na própria comunidade, além da venda de animais, trabalho como diarista, e programas públicos, principalmente Bolsa Família. Mas a principal fonte de receita da família feirante é a feira.

Neste artigo as receitas foram estimadas de forma indireta, com base nos gastos dos consumidores. Na Tabela 5, a seguir, estão expostas as receitas semanais e mensais de feirantes, por município; em todos, a receita média mensal do feirante ultrapassava 1,5 salário mínimo, numa média geral de 3,43 salários mínimos por feirante/mês. Esta receita média recebe forte influência das receitas altas de Itamarandiba, e varia muito entre os municípios. E é preciso ponderar ainda que são médias, que podem ocultar grandes desníveis de receitas entre feirantes. 
Tabela 5: Receita média semanal e mensal dos feirantes, por município e total (2018)

\begin{tabular}{lccccc}
\hline \multicolumn{1}{c}{ Município } & $\begin{array}{c}\text { Receita total } \\
\text { semanal }(\mathrm{R} \$)\end{array}$ & $\begin{array}{c}\text { Número } \\
\text { de } \\
\text { feirantes }\end{array}$ & $\begin{array}{c}\text { Receita média } \\
\text { semanal } \\
\text { feirante }(\mathrm{R} \$)\end{array}$ & $\begin{array}{c}\text { Receita média } \\
\text { mensal feirante } \\
(\mathrm{R} \$)\end{array}$ & $\begin{array}{c}\text { Receita em } \\
\text { salários mínimos } \\
2018(*)\end{array}$ \\
\hline $\begin{array}{l}\text { Chapada do } \\
\text { Norte }\end{array}$ & $28.453,75$ & 45 & 632,31 & $2.845,40$ & 2,98 \\
Itamarandiba & $339.460,20$ & 302 & $1.124,04$ & $5.058,18$ & 5,30 \\
Minas Novas & $64.955,52$ & 160 & 405,97 & $1.826,87$ & 1,91 \\
Turmalina & $84.199,50$ & 178 & 473,03 & $2.128,64$ & 2,23 \\
Veredinha & $18.170,00$ & 51 & 356,27 & $1.603,24$ & 1,68 \\
\hline Total & $\mathbf{5 3 5 . 2 3 8 , 9 7}$ & $\mathbf{7 3 6}$ & $\mathbf{7 2 7 , 2 3}$ & $\mathbf{3 . 2 7 2 , 5 2}$ & $\mathbf{3 , 4 3}$ \\
\hline
\end{tabular}

Fonte: pesquisa de campo, 2018. Organizada pelos autores, 2019.

Em comparação com levantamentos feitos na região em 2004 usando a mesma metodologia (RIBEIRO, 2007) é notável a evolução da receita média ao longo do tempo, que passou de 1,18 para 3,43 salários mínimos. E essas receitas são também importantes quando comparadas ao Fundo de Participação dos Municípios (FPM), principal fonte de receita das prefeituras: em Itamarandiba correspondem a 96,47\% das receitas do FPM, em Chapada do Norte, o menor percentual, representa 12,83\%, atingindo percentuais relevantes nos demais municípios. Receitas de feiras em Itamarandiba atingem três vezes o montante das transferências do Programa Bolsa Família; em Turmalina representam praticamente o dobro, e nos demais municípios fica em torno de $60 \%$ do valor dessas transferências, mostrando a importância das receitas criadas no próprio município frente às transferências, conforme a Tabela 6, abaixo.

Tabela 6: Receita das feiras livres como percentual de receitas do Fundo de Participação dos Municípios e transferência do Programa Bolsa Família, por município (2018)

\begin{tabular}{lcc}
\hline Município & $\begin{array}{c}\text { Fundo de Participação } \\
\text { dos Municípios }\end{array}$ & $\begin{array}{c}\text { Programa Bolsa } \\
\text { Família }\end{array}$ \\
\hline Chapada do Norte & 12,83 & 64,13 \\
Itamarandiba & 96,47 & 333,27 \\
Minas Novas & 18,47 & 59,49 \\
Turmalina & 31,57 & 174,85 \\
Veredinha & 13,65 & 65,53 \\
\hline
\end{tabular}

Fontes: Receitas de feirantes: pesquisa de campo, 2018; FPM: Tesouro Transparente, 2019; Programa Bolsa Família: Portal da Transparência, 2019; organizada pelos autores, 2019.

Apesar da importância da dimensão econômica, nem sempre feirantes conseguem vender tudo que levam à feira. Produtos pouco perecíveis, como as farinhas, fubá, rapadura e doces, podem ser armazenados, e alguns feirantes os armazenam no próprio mercado para oferecer novamente na próxima feira. E, baseados na experiência, feirantes 
já calculam a quantidade de produtos perecíveis, como verduras e frutas, que levam à feira, para não correr o risco de perdas. Mas sempre sobram, e seu destino é variado. A maior parte dos feirantes $(44,50 \%)$ opta por voltar com os produtos para casa, mas um terço deles $(20,43 \%)$ prefere doar as sobras. E existem outras opções: venda no comércio urbano $(9,48 \%)$, vendas pela rua $(8,02 \%)$, e uma porção reduzida dos feirantes destina as sobras para programas institucionais de compras $(4,37 \%)$, faz trocas na própria feira $(2,18 \%)$, vende na comunidade rural $(1,45 \%)$, guardam na banca para a próxima feira $(0,72 \%)$, e não informaram (4,37\%). Aqui faz-se uma observação: a somatória das respostas ultrapassa o número de feirantes porque os entrevistados indicaram mais de uma alternativa.

Alguns feirantes raramente têm sobras, porque seus produtos se diferenciam pelos atributos: pelo processo artesanal, pelo gosto peculiar, ou pela combinação da técnica material com a base de recursos. Assim, carregam a fama do produtor e do lugar de origem, que se transforma em referência de qualidade reputada, de vendas e preços. $\mathrm{O}$ consumidor leva consigo o produto e a assinatura do artesão: rapadura do Noel, requeijão da Aparecida de Bom Sucesso, doce da Mariana, farinha de Salgadinho e Santa Joana em Itamarandiba; farinha de milho de Gleiciane, rapadura de Batieiro, em Chapada do Norte; doce de dona Côca, farinha de mandioca de Ribeirão dos Santos Acima, em Minas Novas; farinha de milho da Lia, produto da horta do Valdir, requeijão de seu Dau, em Turmalina; farinha de Toninho Bernardino, rapadura de Valdemar da Gameleira, bolo cobú de Leda, em Veredinha. São referências de excelência, produtos principalemente da indústria doméstica rural que vinculam saber-fazer, valor cultural e afirmação de gosto próprio do território. Esses produtos agregam ao valor econômico o elevado valor cultural reconhecido pelo comprador.

Nesses, mas também em outros produtos, há rigoroso controle de qualidade, denominado pelos feirantes como "capricho" - referência aos cuidados com preparo dos produtos, higiene, embalagem, armazenamento, transporte e, sobretudo, respeito ao gosto do território. O capricho é testado toda semana no corpo-a-corpo do feirante com o comprador, que comenta, compara e negocia a qualidade, tanto quanto negocia o preço. É o controle de qualidade que leva ao reconhecimento do agricultor feirante "caprichoso", 
e daí vem a fama que diferencia produtor e produto, conforme também notaram Angulo (2002), Ribeiro (2007) e Servilha (2008).

Abastecendo pequenas cidades com alimentos, qualidade e receitas, feiras acabam por receber apoios de instituições estatais e da sociedade civil que oferecem suporte para fortalecer as atividades de agricultores. Este tipo de apoio vem da Prefeitura, Emater, Fundo Cristão para Crianças, Governo Estadual, Governo Federal, Sindicato de Trabalhadores Rurais, associações comunitárias, associações de feirantes e CAV. Esses apoios se manifestam no auxílio à organização, em programas de abastecimento de água, extensão rural, fundos rotativos de crédito e acesso ao crédito rural. Mas, na condição de feirantes, a demanda por suporte é mais modesta e pontual: se resume a infraestrutura do Mercado Municipal, organização da feira, aumento do número de bancas, manutenção do transporte e vias de acesso à cidade. As dificuldades, em ritmos diversos, vão sendo resolvidas; e não impedem que as feiras aconteçam, abasteçam as cidades, dinamizem seu comércio.

\section{Considerações finais}

Feiras livres geram ocupação e receitas para milhares de agricultores familiares do vale do Jequitinhonha; integram campo e cidade, fortalecem circuitos de comercialização de pequena escala, contribuem para o consumo de alimentos produzidos nas proximidades. Desse modo, as feiras conformam mercados peculiares, que têm normas próprias de funcionamento e formação de preço, que se baseiam no relacionamento próximo entre produtor e consumidor, que a cada encontro semanal reconstroem relações de confiança e padrões específicos de qualidade e gosto que orientam a produção costumeira. Embora acontecem em espaços geridos pelas prefeituras, as feiras têm dinâmica própria, definida por agricultores feirantes e compradores, que convertem o espaço dos mercados em bens coletivos e autogeridos, recursos governados pelo costume e por relações entre pessoas.

Essas relações discretas, informais, cotidianas, sólidas e perenes, dão vida a, pelo menos, dois movimentos muito importantes.

Primeiro, a um movimento econômico que sustenta e anima uma agricultura familiar excluída dos grandes circuitos de trocas, aninhada num território que ficou à 
margem de parte dos efeitos da revolução verde. Chama atenção nas feiras livres do Jequitinhonha, depois de um estudo rigoroso, a dimensão de um fenômeno econômico construído a partir de ações cotidianas e, sobretudo, ocultas: os dados de Censo e as pesquisas de renda não percebem esse movimento singular que se repete, constantemente em silêncio.

Segundo, a feira desvela o rosto do Território. Na feira os consumidores reconhecem suas preferências e costumes alimentares, feira materializa a relação daquela população com seus alimentos. Desse modo, são igualmente importantes para a caracterização cultural, social, econômica e ambiental do território. O agricultor do Alto Jequitinhonha tem sido resiliente às intempéries do tempo, vive na labuta diária da roça, mostra orgulho do seu ofício e pretende ser valorizado por isso. E os agricultores se empoderam como sujeitos sociais que enfrentam o modelo excludente de desenvolvimento e criam estratégias para se firmar nesses mercados tão próximos do seu cotidiano e tão apartados dos grandes negócios.

\section{REFERÊNCIAS}

ABRAMOVAY, R. O capital social dos territórios. Economia Aplicada. N.2, vol IV: 379-397, abril/junho 2000.

ALVES, R. L. Bem dito e bem feito: a dimensão espetacular das performances narrativas de feirantes rurais do Alto Jequitinhonha. 174 f. Dissertação (mestrado em Artes) - Universidade Federal de Uberlândia / Uberlândia, 2015.

ANGULO J. L. G. Feira e desenvolvimento local: o caso de Turmalina, vale do Jequitinhonha, MG. 138 f. Dissertação (mestrado em Administração), PPGAD/UFLA / Lavras, 2002.

ANJOS, F. S., GODOY, W. I. \& CALDAS, N. V. As feiras livres de Pelotas sob o impacto da globalização. Pelotas: Editora e Gráfica da UFPel, 2005. 197 p.

ARAÚJO, A. M.; RIBEIRO, E. M. Feiras, feirantes e abastecimento: uma revisão da bibliografia brasileira sobre comercialização nas feiras livres. Estudos Sociedade e Agricultura, Rio de Janeiro, v. 26, n. 3, p. 561-583, outubro de 2018.

BAUER, M. W.; GASKELL, G. Pesquisa qualitativa com texto, imagem e som: um manual prático. Petrópolis: Vozes, 2002. 516 p. 
BRANDÃO, C. R. Saber de classe e educação popular. IN $\mathrm{O}$ ardil da ordem. Campinas, Papirus, 1986. V.1.

BUSSAB, W. O.; MORETTIN, P. A. Estatística básica. 5 ed. São Paulo: Saraiva, 2004.

CALDAS, A. L. T. O vale do Jequitinhonha em números: análise quantitativa da MRH de Capelinha a partir de quatro bancos de dados. $163 \mathrm{f}$. Trabalho de conclusão de curso, (Graduação em Agronomia) - Instituto de Ciências Agrárias, ICA/UFMG, Montes Claros, 2018.

COÊLHO, J. D. Feiras livres de Cascavel e Ocara: caracterização, análise da renda e das formas de governança dos feirantes. 152 f. Dissertação (mestrado em Economia Rural), Fortaleza, 2008.

CNPq. Relatório de pesquisa do Edital CNPq 33/2009, processo 558411/2009-6. Formação de rede de trocas de saberes sobre beneficiamento e comercialização de produtos da agroindústria doméstica e artesanais da agricultura familiar do alto Jequitinhonha. Brasília, CNPq, 2012.

DAYRELL, C. A., BARBOSA, R. S., \& COSTA, J. B. DE A. Dinâmicas produtivas e territoriais no Norte de Minas: o lugar invisível das economias nativas e apontamentos para políticas públicas. CAMPO-TERRITÓRIO: revista de geografia agrária. V. 12, N. 27, 2017.

DIEGUES, A. C. Repensando e recriando as formas de apropriação comum dos espaços e recursos naturais. IN _ Povos e mares: leitura em sócio-antropologia marítima. São Paulo: NUPAUB/USP, 1995.

FUNDAÇÃO JOÃO PINHEIRO. Plano de Desenvolvimento do Vale Jequitinhonha, Belo Horizonte, Fundação João Pinheiro, 2017.

GALIZONI, F. M. A terra construída. Fortaleza: Etene/BNB, 2008.

GALIZONI, F. M.; SILVA, E. P. F.; MOREIRA, T. M. B.; CALDAS, A. L. T.; MALTEZ, M. A. P. F. Mantimento, alimento, sustento. IN RIBEIRO, E. M. (org.) Do engenho à mesa - Cultura material e indústria rural na agricultura familiar no Jequitinhonha Mineiro. 1 ed. Belo Horizonte: Editora UFMG, 2019. 324 p., p. 81 - 103.

GARCIA, M. F. Negócio e campesinato: uma estratégia de reprodução social. Boletim do Museu Nacional. Antropologia, Rio de Janeiro, n. 45, p. 1-17, 1983.

GARCIA, M. F. O segundo sexo do comércio: camponesas e negócio no Nordeste do Brasil. Revista Brasileira de Ciências Sociais. v.7, n.19. Rio de Janeiro: Anpocs, 1992. 
GIL, A. C. Como elaborar projetos de pesquisa. 4a . ed. São Paulo: Atlas, 2002. 176 p.

HEREDIA, B. M. A morada da vida - Trabalho familiar de pequenos produtores no nordeste do Brasil. Rio de Janeiro: Paz \& Terra, 1979.

IBGE - Instituto Brasileiro de Geografia e Estatística. Censo Agropecuário, 2006.

IBGE - Instituto Brasileiro de Geografia e Estatística. Censo Demográfico, 2010. ICA/UFMG. Relatório de pesquisa sobre as feiras de Chapada do Norte e Turmalina. Montes Claros, 2015.

LAVILLE C., DIONNE J. A construção do saber - manual de metodologia da pesquisa em ciências humanas. Belo Horizonte, Editora UFMG, 1999. 340 p.

MARQUES, P. E. M. Embates em torno da segurança e soberania alimentar: estudo de perspectivas concorrentes. Segurança Alimentar e Nutricional, v. 17, n. 2, p. 78-87, 2010.

MEIRELLES, L. Soberania alimentar, agroecologia e mercados locais. Agriculturas, v. 1, n. 0, p. 11-14, 2004.

PALMEIRA, M. Feira e mudança econômica. Brasília, v.11, n.1, p. 324-360, Vibrant, junho, 2014.

PECQUEUR, B. O desenvolvimento territorial: uma nova abordagem dos processos de desenvolvimento para as economias do Sul. Raízes, Campina Grande, v. 24, nos 01 e 02, p.10-22, jan./dez. 2005.

PLOEG, J. D. V. Camponeses e impérios agroalimentares. Porto Alegre: Editora UFRGS, 2008. 376 p.

Portal da Transparência: http://www.portaltransparencia.gov.br. Consultado em 21/07/2019.

RIBEIRO, E. M., CASTRO, B. S.; RIBEIRO, J. A. A feira livre de Minas Novas: abastecimento urbano, consumo e renda para a agricultura familiar. Relatório de pesquisa. Lavras, Turmalina, Minas Novas, 2004.

RIBEIRO, E. M.(Org.). Feiras do Jequitinhonha: Mercados, cultura e trabalho de famílias rurais no Semi-Árido de Minas Gerais. Fortaleza, Etene/BNB, 2007. 244 p.

RIBEIRO, E. M. (org.) Sete estudos sobre a agricultura familiar do Vale do Jequitinhonha. Porto Alegre: Editora da UFRGS, 2013. 192 p.

RIBEIRO, E. M. AYRES, E. C. B.; GALIZONI, F. M.; PEREIRA, V. G. Programas Sociais, mudanças e condições de vida na agricultura familiar do vale Jequitinhonha 
mineiro. Revista de Economia e Sociologia Rural, Piracicaba-SP, v.52, n. 2, p. 336386, 2014.

SABOURIN, E. Aprendizagem coletiva e construção social do saber local: o caso da inovação na agricultura familiar da Paraíba. Rio de Janeiro, Estudos Sociedade e Agricultura, Rio de Janeiro, V. 9, n. 1, p. 37-61, 2001.

SANTOS, H. F. Modernização seletiva da agricultura brasileira e expropriação sócio econômica no campo. CAMPO-TERRITÓRIO: revista de geografia agrária. V.11, n. 24, 2016.

SERVILHA, M. M. As relações de trocas materiais e simbólicas no mercado municipal de Araçuaí. 166 f.Dissertação (mestrado em Extensão Rural). Universidade Federal de Viçosa, 2008.

Tesouro Transparente. https://www.tesourotransparente.gov.br. Consulta 21/07/2019.

WOORTMANN, E. F.; WOORTMANN, K. O trabalho da terra: a lógica e a simbólica da lavoura camponesa. Brasília: Editora UnB, 1997. 192 p.

Recebido em 23/09/2019.

Aceito para publicação em 30/04/2020. 